\title{
Bacterial Leaf Spot of Lettuce: An Unpredictable Enemy to the Florida Lettuce Industry ${ }^{1}$
}

\section{Germán Sandoya and D. Calvin Odero²}

\section{Lettuce as Crop}

After China, the United States is the second largest lettuce producer worldwide, followed by India, Spain, and Italy. The main states producing lettuce are California and Arizona, with approximately 250,000 and 72,000 acres planted, respectively. The crop represents a $\$ 3.5$ billion business in the country. It is cultivated on approximately 10,000 acres in the state of Florida, the third largest state producer, with a farmgate value of approximately $\$ 80$ million (Sandoya and Lu 2013). Approximately $90 \%$ of lettuce cultivation in Florida occurs in the Everglades Agricultural Area (EAA) and the remaining $10 \%$ in protected structures throughout the state. This article describes crop management practices required for field lettuce production in Florida to assist growers in making management decisions to help control bacterial leaf spot in lettuce.

\section{The Disease}

Bacterial leaf spot of lettuce (BLS) was discovered in the United States over 100 years ago in South Carolina (Brown 1918). As lettuce acreage increased in the country, the disease became more prominent in major production areas in California and later in Florida because it is favored by the warm, humid conditions during the lettuce season in south Florida, which lasts from October (planting) until mid-April (last harvesting) (Sandoya et al. 2019). BLS is an unpredictable threat to the lettuce cultivated on soils with rich organic matter called muck soils in the EAA located on the southern edge of Lake Okeechobee. Leafy vegetable growers there have lost several crops due to BLS outbreaks that occurred in the 1980s, 1990s (Pernezny et al. 1995), and 2010s. Smaller outbreaks that were kept under control occurred in the region during the 2017-2018 and 2019-2020 lettuce seasons.

There is no clear evidence so far as to how this disease is spread to uninfected fields or how it was initially introduced into lettuce fields in the state. Lettuce seed infested with BLS is suspected to be the main mode of transmission, but weeds are also considered to play an important role in the epidemiology of the disease (Koike et al. 2018). Further research on these topics will clarify the actual transmission mechanisms and will help to design control strategies that minimize the effects of BLS in lettuce.

\section{Causal Agent}

Initially, BLS was believed to be caused by the bacterium, Xanthomonas campestris pv. vitians, a pathovar that only causes the disease in lettuce. However, the causal agent of lettuce BLS was recently reclassified as X. hortorum $\mathrm{pv}$. vitians (Morinière et al. 2020). Xanthomonas hortorum pv. vitians is a gram-negative bacterium that produces yellow colonies on nutrient agar (NA) (Figure 1).

1. This document is HS1412, one of a series of the Horticultural Sciences Department, UF/IFAS Extension. Original publication date May 2021. Visit the EDIS website at https://edis.ifas.ufl.edu for the currently supported version of this publication.

2. Germán Sandoya, assistant professor, Horticultural Sciences Department; and D. Calvin Odero, associate professor, Agronomy Department, UF/IFAS Everglades Research and Education Center, Belle Glade, FL 33430.

The Institute of Food and Agricultural Sciences (IFAS) is an Equal Opportunity Institution authorized to provide research, educational information and other services

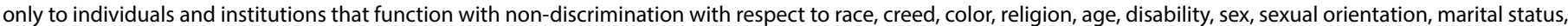

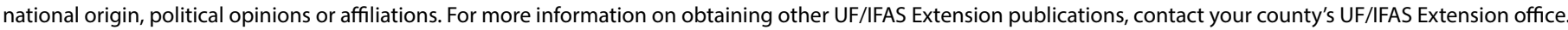
U.S. Department of Agriculture, UF/IFAS Extension Service, University of Florida, IFAS, Florida A \& M University Cooperative Extension Program, and Boards of County Commissioners Cooperating. Nick T. Place, dean for UF/IFAS Extension. 


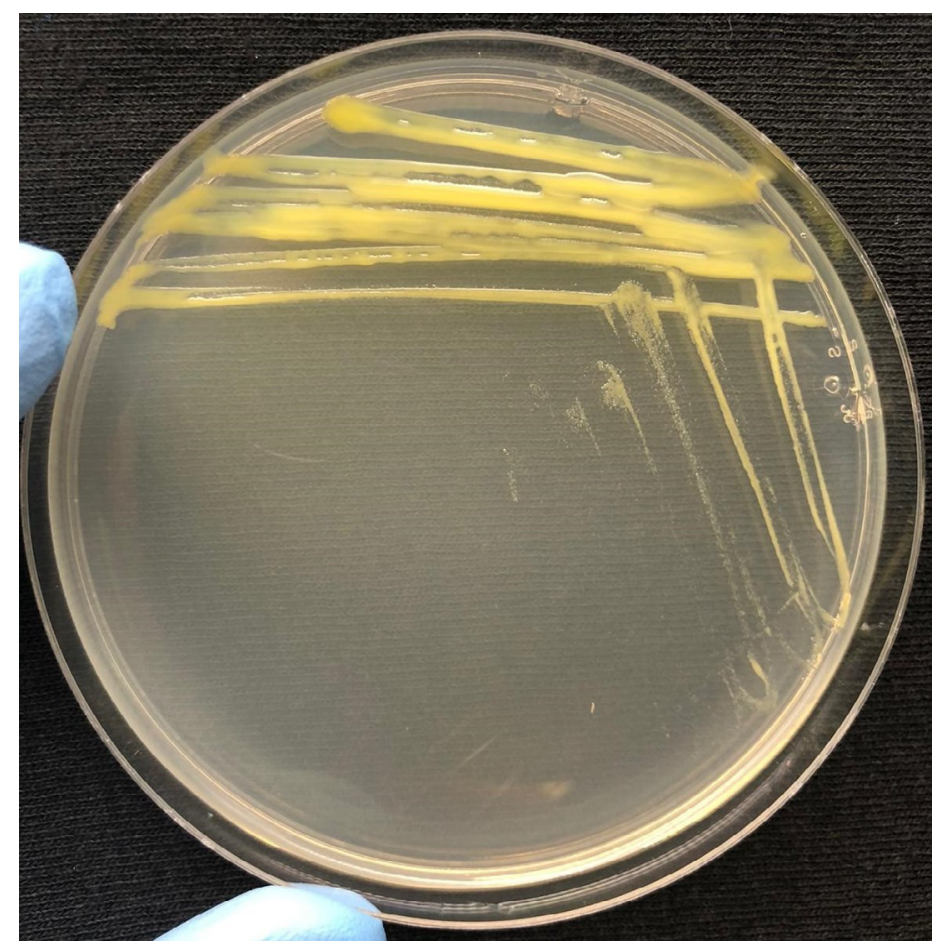

Figure 1. Xanthomonas hortorum pv. vitians (formerly known as $X$. campestris pv. vitians) colonies on NA.

Credits: Amanda Carroll, UF/IFAS

There are three known races of the pathogen to date, identified as races 1, 2, and 3 (Bull et al. 2016). Race 1 isolates have been recovered from all lettuce production areas in the United States, including Florida. Races 2 and 3 have not yet become a threat to the Florida lettuce industry but may cause outbreaks in other regions, including California and Michigan (Koike et al. 2018). Precautions should be in place to avoid the introduction of other races to the state of Florida.

\section{Symptoms}

Xanthomonas hortorum pv. vitians infects all types of lettuce, producing characteristic small, round brown spots with water-soaked lesions. In Figure 2, typical BLS symptoms are shown on romaine and iceberg lettuce, two of the main types of lettuce grown in Florida. Eventually these spots coalesce, become larger, and give the plant a papery feeling to the touch (Figure 3).

\section{Disease Cycle}

Inoculum source is believed to come from contaminated seeds and transplants, depending on the type of planting, and likely in volunteer lettuce or weeds that are hosts to the pathogen. Once the inoculum enters the lettuce plant, symptoms of the disease do not appear until bacterial colonies increase to $10^{7}$ colony-forming units per 0.3 square inch.

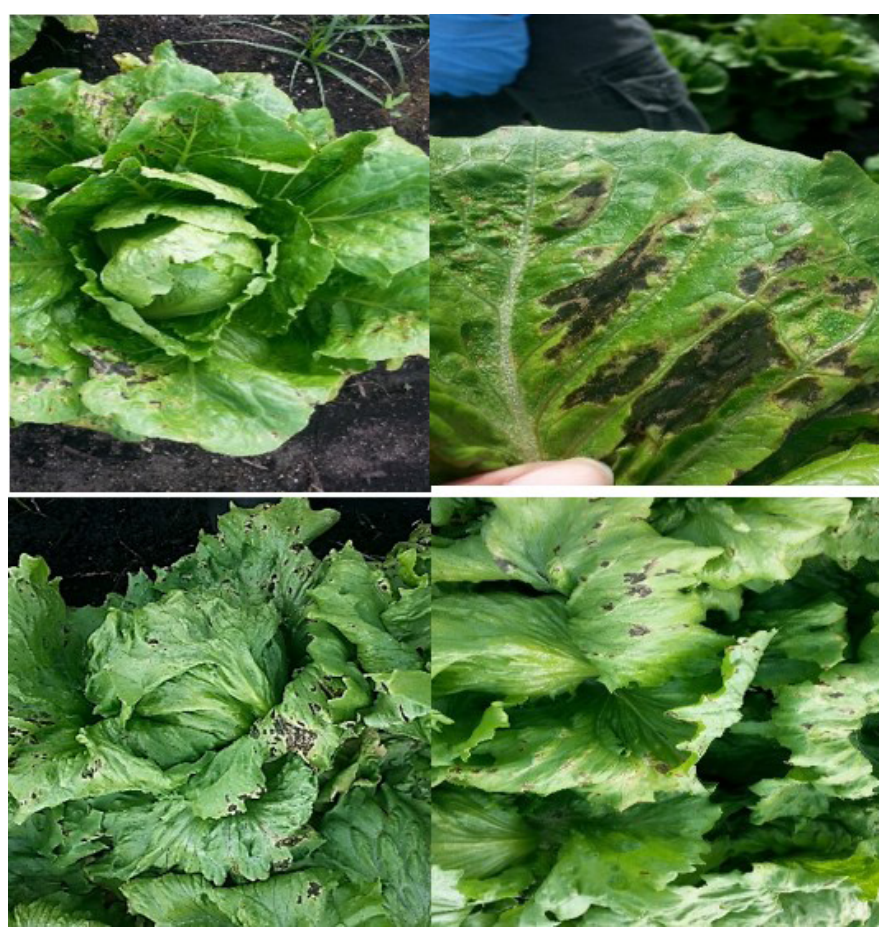

Figure 2. Bacterial leaf spot symptoms in romaine (above) and iceberg (below) lettuce near Belle Glade, FL.

Credits: Richard N. Raid, UF/IFAS

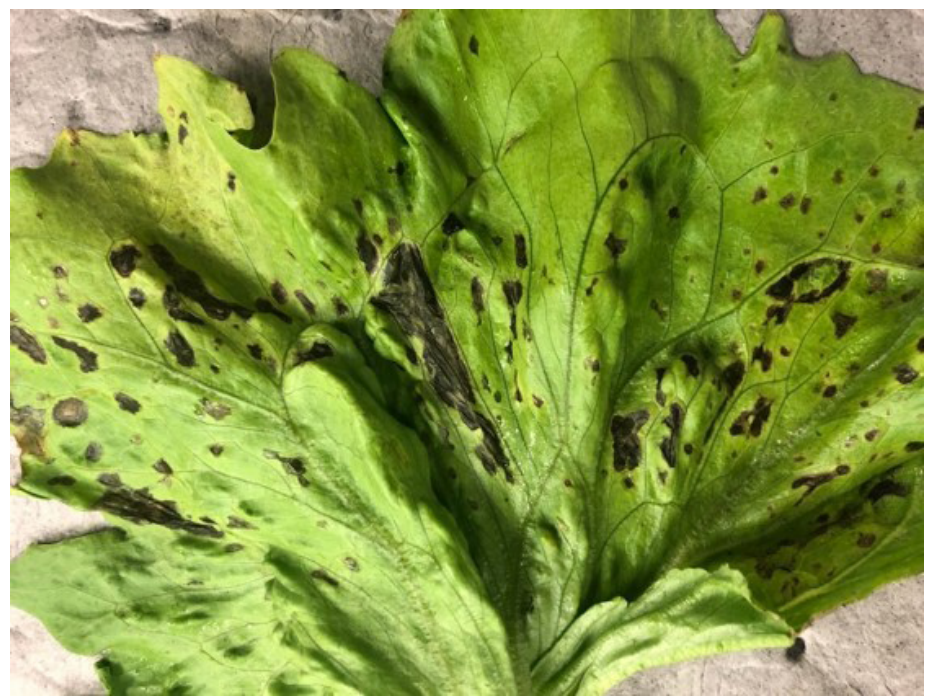

Figure 3. Bacterial leaf spot advanced symptoms in iceberg lettuce near Belle Glade, FL.

Credits: Gustavo Kreutz, UF/IFAS

BLS develops at temperatures above $73^{\circ} \mathrm{F}$. The most likely influencing factor that helps to develop the disease is wet and humid conditions, which in Florida are very high due to the warmer conditions in the state. The pathogen can also survive in crop residue for one to four months in the western United States; however, in Florida the pathogen may not survive after the last crop of the season due to the high temperatures in early spring, summer, and early fall. 
Because the pathogen moves systemically, it is believed that it may be seed transmitted. However, no research has demonstrated the BLS seed transmission mechanism, and further research is necessary.

\section{Management}

Crop destruction at the point of infection and surrounding areas has proved to be effective to avoid other neighboring lettuce fields from becoming infected. This strategy has been successful in containing $X$. hortorum pv. vitians spread to other fields during recent small outbreaks in Florida.

Xanthomonas hortorum pv. vitians is believed to be transmitted in infested seed, which is the most common avenue of disease introduction. The use of disease-free seed is highly recommended, but to date there is no effective method to detect the pathogen on seeds and assure cleanliness from BLS.

The spread of the BLS pathogen is accentuated by rain and overheard irrigation. Although drip irrigation can be used to mitigate spread of the disease by keeping foliage as dry as possible, this cultural practice is not economically feasible in Florida's commercial field production.

Efficacious weed control in surrounding areas of lettuce fields is highly recommended because the pathogen may be epiphytic on weeds (Odero and Sandoya 2019). Additional studies are underway to determine weed species that may be secondary hosts of BLS in the EAA.

There are no bactericides that can eradicate BLS from lettuce production. Copper-based compounds can be effective in reducing the severity and incidence of outbreaks of BLS when the disease first appears (Bull and Koike 2005). However, there is a potential for development of resistance to copper in the pathogen population following repeated applications. The high variability of disease outbreaks each year makes it impossible to predict when preventive applications of copper should be used.

Ultimately, host resistance is the most environmentally friendly and efficient control method against the BLS disease. BLS resistance can be found in certain heirloom lettuce cultivars that are not acceptable for commercial production (Figure 4). Disease resistance towards race 1 strains of the pathogen can be easily transferred to romaine, iceberg, and leaf lettuce cultivars using traditional breeding methods. The UF/IFAS lettuce breeding program is developing multiple lettuce cultivars of different types with resistance against this disease for planting in Florida.

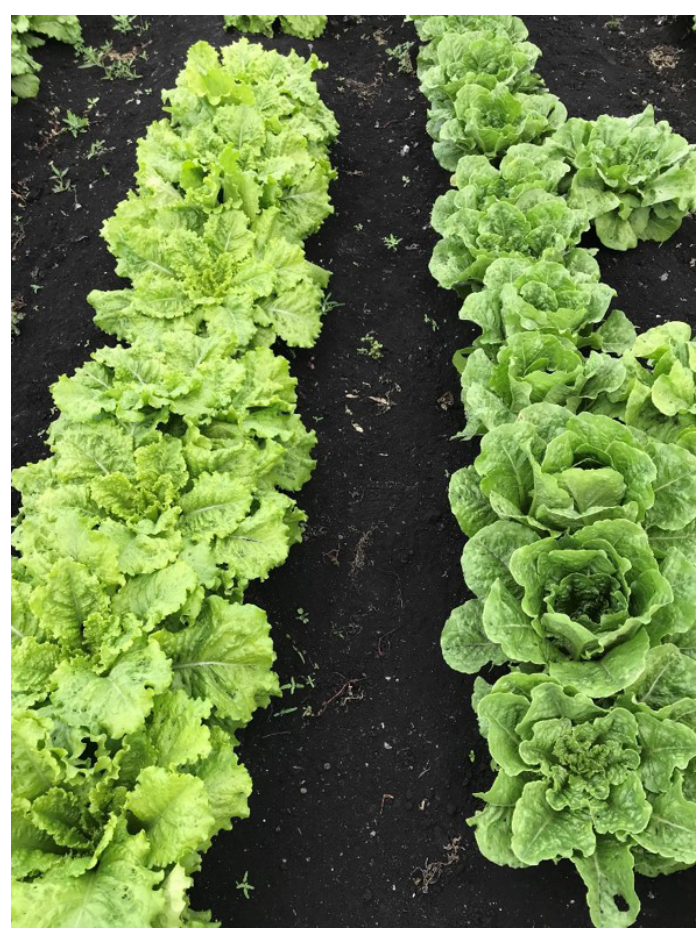

Figure 4. Plant Introduction (PI) 358001-1 (left), an accession resistant to race 1 of Florida strains of $X$. hortorum pv. vitians and UF/IFAS advanced romaine lettuce breeding line (right) with resistance to BLS planted near Belle Glade, FL.

Credits: Germán Sandoya, UF/IFAS

\section{References}

Brown, Z. 1918. "Some Bacterial Diseases of Lettuce." Journal of Agriculture Research 13:367-388.

Bull, C. T., P. H. Goldman, R. Hayes, L. V. Madden, S. T. Koike, and E. Ryder. 2007. "Genetic Diversity of Lettuce for Resistance to Bacterial Leaf Spot Caused by Xanthomonas campestris pv. vitians." Plant Health Progress 8 (1). https:// doi.org/10.1094/PHP-2007-0917-02-RS

Bull, C. T., and S. T. Koike. 2005. "Evaluating the Efficacy of Commercial Products for Management of Bacterial Leaf Spot on Lettuce." Plant Health Progress 6 (1). https://doi. org/10.1094/PHP-2005-1121-01-RS

Bull, C., M. Trent, and R. Hayes. 2016. "Three Races of Xanthomonas campestrispv. vitiansCausing Bacterial Leaf Spot on Lettuce Identified." Poster. American Phytopathological Society Annual Meeting 437-P.

Koike, S. T., R. L. Gilbertson, and C. T. Bull. 2018. "Bacterial Leaf Spot." In Compendium of Lettice Diseases and Pests, 2nd edition, edited by Krishna V. Subbarao, R. M. D., Robert L. Gilbertson, and Richard N. Raid, 54-56. St. Paul: The American Phytopathological Society. 
Morinière, L., A. Burlet, E. R. Rosenthal, X. Nesme, P. Portier, C. T. Bull, C. Lavire, M. Fischer-LeSaux, and F. Bertolla. 2020. "Clarifying the Taxonomy of the Causal Agent of Bacterial Leaf Spot of Lettuce through a Polyphasic Approach Leads to Combine Xanthomonas hortorum Vauterin et al. 1995 and Xanthomonas cynarae Trébaol 2000 emend. Timilsina et al. 2019." Systematic and Applied Microbiology43 (4): 126087. https://doi.org/10.1016/j. syapm.2020.126087

Odero, C. D., and G. Sandoya. 2011. "Weeds and Epidemiology of Bacterial Leaf Spot of Lettuce in the Everglades Agricultural Area." EDIS2011 (3). https://edis.ifas.ufl.edu/ ag357

Pernezny, K., R. N. Raid, R. E. Stall, N. Hodge, and J. Collins. 1995. "An Outbreak of Bacterial Spot of Lettuce in Florida Caused by Xanthomonas campestrispv. vitians." Plant Disease 79:359-360. https://doi.org/10.1094/

PD-79-0359

Sandoya, G., and H. Lu. 2013. "Evaluation of Lettuce Cultivars for Production on Muck Soils in Southern Florida.” EDIS2013 (5). https://edis.ifas.ufl.edu/hs1225

Sandoya, G. V., B. Maisonneuve, M. J. Truco, C. T. Bull, I. Simko, M. Trent, R. J. Hayes, and R. W. Michelmore. 2019. "Genetic Analysis of Resistance to Bacterial Leaf Spot in the Heirloom Lettuce Cultivar Reine des Glaces." Molecular Breeding 39 (12): 160. https://doi.org/10.1007/ s11032-019-1072-6

Strayer-Scherer, A., Y. Liao, P. Abrahamian, S. Timilsina, M. Paret, T. Momol, J. Jones, and G. Vallad. 2019. "Integrated Management of Bacterial Spot on Tomato in Florida." EDIS 2019 (6). https://doi.org/10.32473/edis-pp353-2019 